Vol 1, No. 1 (2020), June 2020

E-ISSN: 2746-2471

\title{
EVALUASI STRATEGI PEMASARAN DALAM USAHA MIKRO SOTO MIE BOGOR
}

\author{
Oleh: \\ Novi Dianti ${ }^{1}$ \\ Endah Widati ${ }^{2}$ \\ Program Studi Pendidikan Ekonomi \\ Fakultas Ilmu Pendidikan dan Pengetahuan Sosial \\ Universitas Indraprasta PGRI \\ Email: \\ 1)2) endahwidati82@gmail.com
}

\begin{abstract}
ABSTRAK
Tujuan dari penelitian ini adalah untuk mengetahui seberapa efektif dan efisien strategi pemasaran yang telah dijalankan oleh pemilik usaha mikro Soto Mie Bogor. Adapun metode penelitian yang digunakan dalam penelitian ini adalah metode evaluasi kualitatif. Setelah melakukan analisis dan evaluasi strategi pemasaran yang diterapkan pada usaha mikro soto mie bogor akhirnya dapat ditarik simpulan bahwa strategi pemasaran yang diterapkan oleh usaha mikro soto mie Bogor yang dimiliki oleh Pak Jaja di daerah Munjul belum efektif. Hal ini karena dari hasil perhitungan penjualan selama berdiri sejak tahun 2013 dan 2014 mengalami peningkatan, tetapi ditahun berikutnya yaitu 2015 sampai tahun 2018 hasil penjualan menunjukkan penurunan signifikan. Berdasarkan data yang diperoleh menunjukkan bahwa harga yang ditetapkan tidak sesuai dengan total biaya setiap produk yang ditawarkan. Analisis VRIO dengan kinerja diatas normal yaitu sumber daya letak geografis dan sumber daya produk. Analisis PESTL yang menjadi peluang dilihat dari segi ekonomi dan sosial, sedangkan yang menjadi ancaman adalah legalitas.
\end{abstract}

Kata Kunci: Strategi Pemasaran, Usaha Mikro, Evaluasi 
Vol 1, No. 1 (2020), June 2020

E-ISSN: 2746-2471

\section{A. PENDAHULUAN}

Bisnis makanan (kuliner) merupakan salah satu bisnis yang berkembang pesat dan memiliki potensi berkembang yang cukup besar. Sudah banyak pelaku usaha yang meraup keuntungan dari usaha kuliner ini. Namun tidak sedikit pula pelaku usaha kuliner yang gulung tikar alias bangkrut, karena strategi pemasaran yang digunakan kurang tepat dan kualitas pelayanan yang kurang optimal. Artinya keberhasilan sebuah bisnis kuliner dalam memenangkan persaingan ditentukan oleh penerapan strategi pemasaran yang tepat serta hubungan baik yang dijalani dengan konsumen.

Perubahan gaya hidup, kebiasan, selera dan tata cara dalam menikmati dan mengkonsumsi makanan pada masyarakat perkotaan membuat para pelaku bisnis kuliner semakin kreatif menuangkan ide-ide mengenai usaha makanan. Hal ini membuat konsumen mempunyai banyak alternatif pilihan dalam memilih produk makanan yang di tawarkan oleh adanya kemajuan. Harga, tempat, cita rasa makanan, promosi dan kualitas pelayanan menjadi salah satu daya tarik bagi setiap konsumen untuk berkunjung ke tempat usaha tersebut.

Bagi produsen hal ini merupakan ancaman karena banyak produk makanan dan kuliner yang ditawarkan maka semakin ketat pula persaingan yang terjadi dalam dunia kuliner. Persaingan yang ketat ini menuntut para pelaku bisnis untuk mampu menempatkan strategi pemasarang yang tepat.

Sebagai usaha mikro, Soto Mie Bogor merupakan usaha yang menjanjikan karena merupakan makanan tradisional khas Bogor yang sudah popular di wilayah Jabodetabek. Namun dengan pengelolaan yang kurang baik terutama perencanaan di bidang pemasaran membuat hanya sedikit usaha Soto Mie Bogor yang diketahui berkembang. Umumnya usaha soto mie bogor yang berkembang berada di kota asal yaitu kota Bogor. Adapun usaha soto Mie Bogor yang sudah berkembang adalah Soto Mie Bogor Ohim (Bogor), Soto Mie Bogor Kesatuan (Bogor), Soto Mie Bogor Agil (Bogor), Soto Mie Ciseeng (Bogor), Soto Mie Bogor Taman Yasmin (Bogor), Soto Mie Bogor Oding (Bekasi) dan Soto Mie Bogor Katineung Pak Subarkah (Cibinong) sedangkan di wilayah Jakarta memang sulit terditeksi karena secara aset dan juga perkembangannya tidak banyak informasi.

Kelurahan Munjul merupakan salah satu kelurahan yang terlatak di Jakarta Timur. Kelurahan Munjul memiliki 6 sarana perekonomian yang terdiri dari 1 pasar, 2 pabrik, 5 toko modern (mini market), dengan jumlah 5, warung dengan jumlah 93, pedagang K-5 dengan jumlah 74 dan material dengan jumlah 5. Selain itu di Kelurahan Munjul memiliki usaha kuliner makanan sebanyak 8 jenis usaha kuliner yang berbeda-beda tiap jenis usahanya. Dengan jumlah tempat atau warung sebanyak 15 kios.

Kemampuan untuk dapat masuk dan bertahan dalam sebuah bisnis atau usaha memerlukan proses dan waktu yang panjang. Sebagai jiwa sebuah usaha, pemasaran menjadi kegiatan penting, beberapa penelitian relevan menunjukkan bahwa penerapan strategi pemasaran di umkm dapat meningkatkan daya saing 


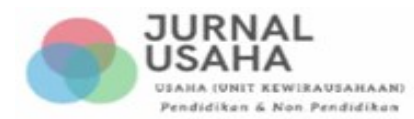

Vol 1, No. 1 (2020), June 2020

E-ISSN: 2746-2471

(Wibowo dan Sunarti, 2015), peluang go international dengan adanya informasi dari teknologi yang digunakan (Elsandra dan Yukianti, 2013) serta mengembangkan usaha dan beradaptasi dengan perubahan lingkungan secara makro (Heriyoga, 2014)

\section{B. KAJIAN PUSTAKA}

Dalam Undang-undang Nomor 20 Tahun 2008 mendefinisikan Usaha mikro adalah usaha produktif milik orang perseorangan atau badan usaha perseorangan yang memenuhi kriteria Usaha Mikro. Kriteria Usaha Mikro yang dimaksud (UU No. 20 tahun 2008, pasal 6) adalah: 1) memiliki kekayaan bersih paling banyak Rp. 50.000.000,- (lima puluh juta rupiah) dan tidak termasuk tanah dan bangunan sebagai tempat usaha ; atau 2) memiliki hasil penjualan tahunan maksimal Rp. 300.000.000,(tiga ratus juta rupiah).

Sedangkan ciri-ciri usaha mikro adalah 1) jenis barang atau komoditi usahanya tidak selalu tetap sewaktu-waktu dapat berg anti; 2) tempat usahanya tidak selalu menetap sewaktu-waktu dapat pindah tempat; 3) belum melakukan adminitrasi keuangan yang sederhana sekalipun dan tidak memisahkan keuangan keluarga dengan keuangan sendiri; 4) Sumber daya manusianya (pengusahanya) belum memiliki jiwa wirausaha yang memadai; 5) tingkat pendidikan rata-rata relatif sangat rendah; 6) umumnya belum akses kepada perbankan, namun sebagian dari para pengusaha sudah akses ke lembaga keuangan non-bank serta 7) umumnya tidak memiliki izin usaha atau persyaratan legalitas lain.

Strategi pemasaran didefinisikan sebagai serangkaian alat untuk mencapai tujuan pemasaran. Strategi pemasaran juga didefinisikan sebagai aktivitas perencanaan menyeluruh (Assauri, 2015; Solihin 2012), pengarahan, pengorganisasian, dan pengendalian berbagai keputusan dan tindakan terkait pencapaian tujuan pemasaran perusahan. (Solihin, 2012). Sebuah usaha atau kegiatan bisnis perlu mengetahi proses strategi pemasaran. Creven dan Piercy (2013) menjelaskan bahwa terdapat 4 (empat) tahap dalam prses strategi pemasaran yaitu 1) mengidentifikasi dan evaluasi pasar, segmen dan pelanggan untuk membuat strategi atau bahkan merubah strategi yang ada; 2) merancang strategi pemasaran berdasarkan pasar; 3) mengembangkan program strategi pemasaran dan 4) implementasi dan pengelolaan strategi pemasaran. Untuk mengembangkan program strategi pemasaran perusahan memerlukan apa yang disebut dengan bauran pemasaran atau marketing mix. Marketing mix adalah serangkaian kombinasi dari beberapa elemen yang digunakan untuk mencapai tujuan pemasaran. Elemen pemasaran yang pertama oleh Mc Carthy (1960, dalam Kotler dan Keller, 2016) dikenal sebagai 4P yaitu Product, Price, Place and Promotion. Namun, keempat elemen tersebut dirasa tidak sesuai jika berkaitan dengan industri jasa, maka Booms dan Bitner (1981) menambahkan 3P yang lain yaitu People, Process and Physical Evidence. Seiring perkembangan, elemen bauran pemasaran pun bertambah yaitu Productivity and Quality (Lovelock dan Wright, 2002). Bagi sebuah usaha rumah makan maka bauran pemasaran yang digunakan adalah 8P yaitu semua elemen yang sudah disebutkan sebelumnya. 
Vol 1, No. 1 (2020), June 2020

E-ISSN: 2746-2471

Beberapa strategi yang dapat dijalankan oleh setiap pemilik dan pengelola usaha dapat dilihat pada tabel 1.

Setiap program yang diimplementasikan harus dievaluasi, baik proses maupun hasil, begitupula dengan program pemasaran. Untuk mengevaluasi strategi dan program pemasaran yang dilaksanakan, pemilik dan pengelola usaha dapat menggunakan beberapa jenis metrics pemasaran (Crevens dan Pierce, 2013) yaitu: metriks pemasaran yang berfokus pada aktivitas program pemasaran, metriks ekuitas merek, metriks inovasi, metriks proses internal dan metriks pasar internal.

Tabel 1. Strategi Bauran Pemasaran

\begin{tabular}{|c|c|c|}
\hline No. & $\begin{array}{l}\text { Elemen Bauran } \\
\text { Pemasaran }\end{array}$ & Strategi \\
\hline 1. & Produk (Product) & $\begin{array}{l}\text { Strategi positioning produk, strategi repositioning produk, } \\
\text { strategi overlap produk, strategi ruang lingkup, strategi } \\
\text { eleminasi produk, strategi produk baru, strategi } \\
\text { diversifikasi, value marketing strategy, (Tjiptono, 2015) }\end{array}$ \\
\hline 2. & Harga (Price) & $\begin{array}{l}\text { Strategi Penetapan harga, strategi penetapan harga produk } \\
\text { yang sudah mapan, strategi fleksibilitas harga, strategi } \\
\text { penetapan harga lini produk, strategi leasing, strategi } \\
\text { bundling pricing, strategi kepemimpinan harga, strategi } \\
\text { penetapan harga untuk meraih pangsa pasar, strategi } \\
\text { peneapan harga jasa (Tjiptono, 2015) strategi penetrasi } \\
\text { harga, strategi skimming harga (Kotler dan Keller, 2016), }\end{array}$ \\
\hline 3. & Saluran Pemasaran (Place) & $\begin{array}{l}\text { Strategi struktur saluran distribusi, strategi cakupan } \\
\text { distribusi, strategy saluran distribusi berganda, strategi } \\
\text { modifikas saluran distribusi, strategi pengendalian saluran } \\
\text { (Tjiptono, 2015) }\end{array}$ \\
\hline 4. & $\begin{array}{l}\text { Komunikasi Pemasaran } \\
\text { (Promotion) }\end{array}$ & $\begin{array}{l}\text { Periklanan, promosi penjualan, acara dan pengalaman, } \\
\text { hubungan masyarakat dan publisitas, pemasaran interaktif, } \\
\text { words of mouth dan penjualan personal (Kotler dan Keller, } \\
\text { 2016) }\end{array}$ \\
\hline 5. & Orang (People) & $\begin{array}{l}\text { Strategi manajemen sumberdaya manusia (Wirtz dan } \\
\text { Lovelock, 2018) }\end{array}$ \\
\hline 6. & Proses (Process) & $\begin{array}{l}\text { Konsumen sebagai co-creators, Self-Services } \\
\text { Technolotgies, pengelolaan penolakan konsumen untuk } \\
\text { berubah (Wirtz dan Lovelock, 2018) }\end{array}$ \\
\hline 7. & $\begin{array}{l}\text { Bukti Fisik } \\
\text { (Physical Evidence) }\end{array}$ & $\begin{array}{l}\text { Holistic view, perspektf konsumen, peralatan medesain } \\
\text { (Writz dan Lovelock, 2018) }\end{array}$ \\
\hline 8. & $\begin{array}{l}\text { Produktivitas dan Kualitas } \\
\text { (Productivity and Quality) }\end{array}$ & $\begin{array}{l}\text { Strategi generik peningkatan produktivitas, pendekatan } \\
\text { fokus konsumen, Cost-Reduction Strategies, Front-Stage } \\
\text { Effort, Back-stage Changes (Wirtz dan Lovelock, 2018) }\end{array}$ \\
\hline
\end{tabular}

Sumber: Berbagai sumber (2020)

\section{METODE PENELITIAN}

Penelitian ini merupakan penelitian evaluasi kualitatif deskriptif (Flick, dkk. 2017) terhadap aktivitas program pemasaran yang dijalankan oleh usaha mikro warung soto mie bogor Pak Jaja, Munjul. Adapun teknik pengumpulan data yang digunakan adalah wawancara dengan pemilik, karyawan dan juga konsumen dengan total 8 orang. Pada penelitian ini juga menggunakan observasi pada setiap proses 
Vol 1, No. 1 (2020), June 2020

E-ISSN: 2746-2471

yang ada pada objek penelitian. Teknik analisis yang digunakan pada penelitian ini adalah analisis lapangan model Huberman dan Miles (2002), analisis resouces based view (Barney, 1991) dan pestle (PESTLEAnalysis.com, 2018) untuk menganalisis lingkungan mikro dan makro objek penelitian serta metrik profitabilitas (Tjiptono dan Chandra, 2015) untuk mengevaluasi penerapan strategi pemasaran yang dilakukan oleh objek penelitian.

\section{HASIL DAN PEMBAHASAN}

Penelitian ini dianalisis berdasarkan tahapan perencanaan, implementasi dan pengendalian strategi (Kotler dan Keller, 2016) yang telah dimodifikasi dengan menambahkan analisis lingkungan sebelum melakukan perencanaan strategi.

1. Analisis Lingkungan

a. Analisis Resources-based View

Pada analisis Resources-based View digunakan kerangka kerja VRIO yang menilai setiap sumber daya yang dimiliki oleh usaha mikro Soto Mie Bogor Pak Jaja yaitu: keuangan, aset tetap, kemampuan organisasi, lokasi geografis dan produk yang ditawarkan.

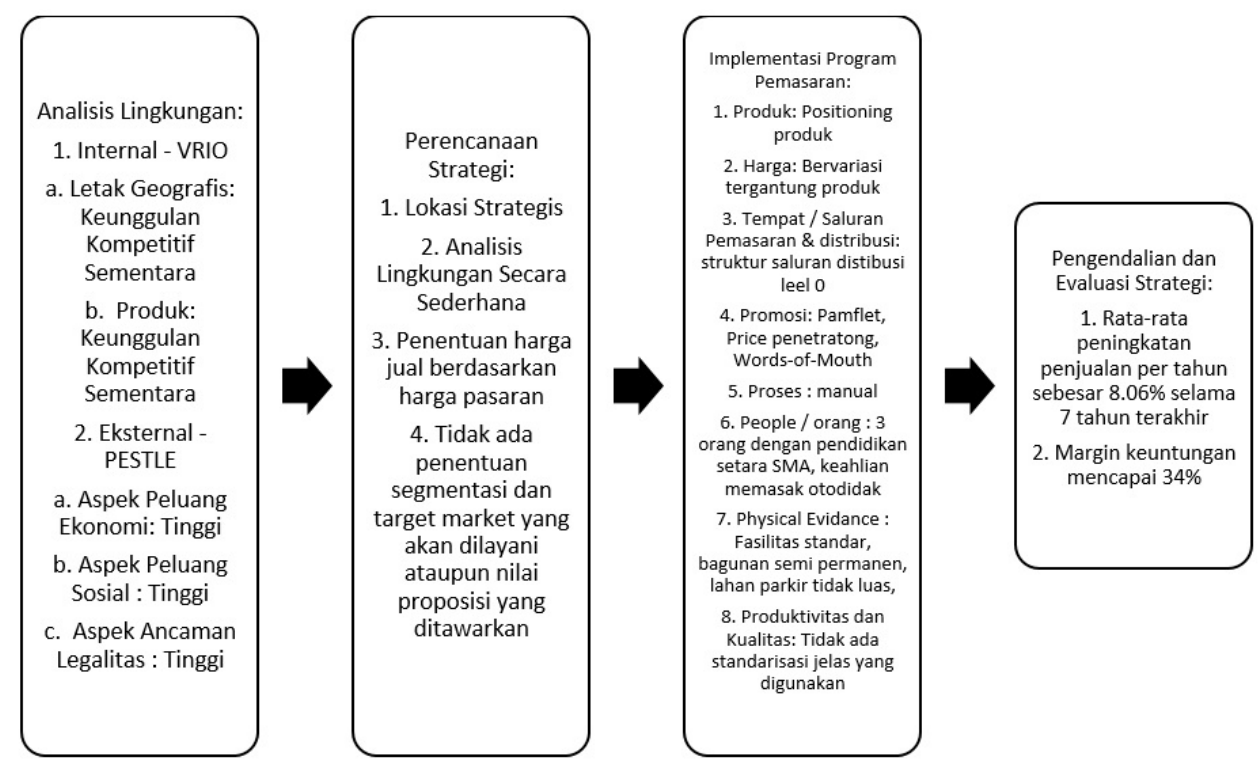

Gambar 1. Rangkuman Hasil Temuan Penelitian

Sumber: Data diolah (2018)

Dilihat dari segi keuangan Soto Mie Bogor Pak Jaja Munjul bahwa sumber modal atau kemampuan yang dimiliki dapat memberikan kesempatan usaha Soto Mie Bogor Pak Jaja Munjul untuk mengeksploitasi kesempatan. Meskipun banyak usaha sejenis yang sama, Soto Mie Bogor Pak Jaja Munjul berusaha mengembangkan dan mengelola sumber modal dan kemampuan keuangan secara maksimal untuk bertahan hingga sekarang 
Vol 1, No. 1 (2020), June 2020

E-ISSN: 2746-2471

di tengah persaingan antar usaha Soto Mie Bogor. Masyarakat juga dengan mudah mendapatkan modal yang sama dengan Soto Mie Bogor Pak Jaja Munjul karena untuk membangun usaha soto mie tidak membutuhkan modal uang yang tidak terlalu besar.

Selanjutnya dari segi aset tetap yang dimiliki oleh Soto Mie Bogor seperti bangunan semi permanen, gerobak Soto Mie Bogor Pak Jaja Munjul, kursi dan meja, serta alat-alat dapur. Pemilik Soto Mie Bogor Pak Jaja Munjul sudah mampu mengelola dan mengembangkan aset tetap yang dimiliki karena pemilik sudah membuat gerobak baru yang dahulunya sudah tidak layak pakai, dan dari bangunan dahulu hanya memakai terpal sekarang sudah memakai asbes, gerobak yang dahulunya memiliki ukuran kecil sekarang sudah memiliki ukuran gerobak yang besar, kursi yang dahulunya hanya 8 kursi sekarang sudah bertambah menjadi 14 kursi dengan jumlah meja 2. Bangunan yang dimiliki oleh Soto Mie Bogor Pak Jaja Munjul dahulu hanya tenda sekarang sudah semi permanen yang terbuat dari bahan triplek dan sudah memakai asbes.

Sedangkan dari segi kemampuan organisasi pengelola Soto Mie Bogor Pak Jaja Munjul mampu melaksanakan tugasnya dengan baik sesuai dengan standar yang diterapkan yaitu disiplin dalam waktu, rapih dalam berpakaian, dan sopan terhadap konsumen yang berkunjung ke tempat Soto Mie Bogor Pak Jaja Munjul. Sehingga tidak berpengaruh terhadap kemampuan organisasi usaha sejenisnya. Kemampuan yang dimiliki oleh setiap karyawan Soto Mie Bogor Pak Jaja Munjul yaitu karyawan harus ramah terhadap konsumen yang datang ke tempat Soto Mie Bogor Pak Jaja Munjul, pintar menyajikan hidangan dan pandai memasak dan karyawan terkadang menggunakan bahasa sunda dalam melayani konsumen jika konsumen mengajak berbicara menggunakan bahasa sunda.

Dalam menjalankan usahanya pengelola tidak memiliki struktur organisasi dan juga standarisasi pengelolaan usaha yang seharusnya sehingga masyarakat dengan mudah mengikuti usaha yang sama karena organisasi yang dijalankan oleh Soto Mie Bogor Pak Jaja Munjul hanya berpacu pada 1 orang saja yaitu istri dari pemilik usaha dan masih menggunakan tata kelola rumah tangga. Dengan demikian dapat disimpulkan bahwa sumber daya keuangan, aset tetap dan kemampuan organisasi memberikan implikasi kemampuan persaingan yang termasuk pada kerugian kompetitif dan memberikan hasil secara ekonomi dibawah normal.

Dilihat dari letak geografis Soto Mie Bogor Pak Jaja Munjul sangat menentukan keunggulan bersaing karena jika lokasi geografis suatu usaha tidak strategis atau terletak ditempat yang salah maka usaha tersebut susah ditemukan oleh konsumen. Untuk Soto Mie Bogor Pak Jaja Munjul untuk tempat lokasinya sangat dekat dengan pasar, perumahan, sekolah, dan kantor Kelurahan Munjul. Dilihat dari letak tempat lokasi banyak usaha 
Vol 1, No. 1 (2020), June 2020

E-ISSN: 2746-2471

yang kuliner namun tidak ada yang sejenis sehingga menjadi suatu keunggulan tersendiri untuk Pak Jaja. Dengan kata lain, letak geografis atau lokasi tempat usaha soto mie bogor Pak Jaja memiliki keunggulan kompetitif sementara dan termasuk pada kategori sumber daya yang memberikan kinerja ekonomis di atas normal.

Dari sisi produk, Soto Mie Bogor Paka Jaja Munjul tidak sulit untuk ditiru konsumen atau masyarakat dapat membuat produk yang sama hanya saja untuk rasa pastinya tidak akan sama persis dengan Soto Mie Bogor Pak Jaja karena resep yang digunakan oleh Soto Mie Bogor Pak Jaja Munjul merupakan resep turun temurun dari nenek moyang Pak Jaja. Sedangkan untuk bahan baku soto masyarakat dapat membeli bahan baku tersebut dengan mudah di pasar. Adapun bahan bakunya berupa daging sapi, jeroan sapi, mie kuning, kikil dan risol, sehingga masyarakat dengan mudah membuat produk yang sama dengan Soto Mie Bogor Pak Jaja Munjul.

b. Analisis PESTLE

Berdasarkan hasil penelitian diketahui beberapa faktor eksternal yang berpengaruh pada perkembangan usaha Soto Mie Bogor Pak Jaja Munjul yang bersifat sebagai peluang maupun ancaman.

1) Ekonomi

Kelurahan Munjul memiliki jumlah penduduk sebanyak 26.658 orang yang terdiri dari laki-laki sebanyak 13.520 orang, sedangkan perempuan sebanyak 13.138 orang. Seperti yang sebelumnya dijelaskan bahwa di Kelurahan Munjul terdapat 6 sarana perekonomian yang terdiri dari 1 pasar, 2 pabrik, 5 toko modern (mini market), warung kelontong sebanyak 93 buah, pedagang K-5 sebanyak 74 dan material sebanyak 5 toko. Berdasarkan tingkat pendapatan, maka penduduk Kelurah Munjul merupakan kelompok masyarakat dengan pendapatan menengah ke bawah atau masyarakat dengan penghasilan Rp. 30.000,- sampai dengan Rp. 300.000,- per hari (setara dengan USD2.0 sampai dengan USD20.0 menurut Asian Development Bank) untuk kelompok kelas menengah dan masyarakat dengan penghasilan dibawah Rp. 30.000,- per hari untuk kelompok kelas bawah. Sebagian peduduk Kelurahan Munjul bekerja sebagai karywan dan buruh serta sebagian besar lain lebih banyak yang memiliki usaha sendiri yang termasuk pada usaha mikro.

Dilihat dari sisi ekonomi, maka jika diasumsikan apabila masyarakat Kelurahan Munjul terbiasa membeli makanan untuk kebutuhan makan sehari-hari maka perputaran ekonomi pun terjadi, hal ini karena juga karena disekitar wilayah Kelurahan Munjul hanya terdapat 15 usaha kuliner yang terdiri dari 2 warung nasi padang, 2 warung kopi (bubur kacang ijo), 3 warung soto, 2 warung tegal, 3 warung mie ayam dan bakso, warung nasi uduk dan warung gado-gado, yang masing-masing berjumlah 1. Sehingga dapat disimpulkan bahwa 
Vol 1, No. 1 (2020), June 2020

E-ISSN: 2746-2471

kesempatan untuk mendapat pelanggan lebih besar karena setiap manusia membutuhkan makanan. Selain itu perubahan gaya hidup masyarakat saat ini yang lebih memilih untuk membeli makanan ketimbang memasak sendiri yang diannggap lebih menyusahkan.

2) Legalitas

Secara legalitas atau hukum, usaha mikro soto mie Bogor milik Pak Jaja belum memiliki izin usaha sehingga dapat dikatakan sebagai usaha illegal, namun Indonesia masih memiliki hukum yang lebih fleksible jika berkaitan dengan usaha mikro. Walaupun untuk saat ini, pemerintah mulai melihat usaha mikro sebagai salah satu sumber penggerak perekonomian sehingga mulai menerapkan beberapa aturan seperti penerapan pajak penghasilan pada usaha mikro kecil dan menengah dan juga penerapan surat domilisi usaha sebelum usaha mikro menengah memiliki Surat Izin Usaha Perdagangan (SIUP).

Hal ini merupakan ancaman bagi keberlangsungan usaha mikro soto mie bogor Pak Jaja karena usaha tersebut belum memiliki izin usaha dan juga belum memiliki surat keterangan domisili usaha dikarenakan ketidak mengertian Pak Jaja dalam mengelola legalitas usaha. Walaupun demikian Pak Jaja sudah meminta izin kepada kepala lingkungan. Sedangkan untuk kewajiban pajak penghasilan umkm Pak Jaja belum membayarkannya dikarenakan pendapataan yang minim. Untuk pajak tanah dan bangunan sudah dibawar

Selain masalah pajak, ketaatan pak Jaja akan peraturan ketenagakerjaan masih jauh dari yang seharusnya. Jika pemerintah menyarankan penerapan UMP / UMK maka Pak Jaja hanya mampu membayar tenaga kerja yang dimiliki sebesar 30\% dari keuntungan harian usahanya.

3) Sosial

Berdasarkan hasil wawancara dan observasi yang dilakukan, diketahui beberapa aspek sosial yaitu kelompok referensi, budaya dan gaya hidup yang mempengaruhi secara langsung keberlangsungan usaha mikro Soto Mie Bogor Pak Jaja. Pertama, dengan banyaknya tayangan baik media sosial maupun media televisi mengenai kuliner, maka kecenderugan masyarakat untuk mencoba sesuatu yang baru menjadi peluang bagi setiap usaha kuliner, begitu pula dengan soto mie bogor. Para penyuka kuliner menjadi salah satu kelompok referensi bagi masyarakat yang ingin menikmati makanan di sebuah daerah yang baru. Hal yang sama diyakini oleh pemilik usaha, bahwa sebagai salah satu warung soto yang menyediakan soto maka pemilik yakin bahwa kelompok referensi dapat memberikan peluang positif bagi usahanya walaupun pada kenyataannya Pak Jaja belum menggunakan kelompok referensi sebagai salah satu media promosi. 
E-ISSN: 2746-2471

Kedua, budaya, dimasyarakat sebuah generalisasi ada bahwa jika ingin merasakan ciri khas dari suatu daerah maka cobalah makanan khas yang dimiliki, demikian pula dengan soto mie bogor. Sebagai salah satu makanan tradisional khas Bogor, maka kurang rasanya jika berkunjung ke Bogor tidak mencoba soto mie bogor. Namun ketika sudah mencoba, maka akan sedikit sulit untuk menemukan rasa yang sama ketika pertama kali mencoba makanan yang sama, umumnya konsumen akan mencari cabang dari usaha soto mie yang dicoba atau yang paling umum adalah mencoba membeli jenis makanan yang sama. Soto mie Bogor Pak Jaja memiliki resep yang diturunkan secara turun temurun sehingga rasa yang didapat sesuai dengan asli resep soto mie Bogor. Ketiga, gaya hidup, berdasarkan hasil penelitian masyarakat Munjul sangat tinggi konsumerisme terhadap produk cepat saji sehingga Soto Mie Bogor Pak Jaja Munjul sangat cocok berusaha di wilayah Munjul.

2. Implementasi Program Pemasaran

a) Produk (Product)

Strategi produk yang digunakan oleh Soto Mie Bogor Pak Jaja Munjul yaitu strategi positioning produk karena mampu menciptakan produk yang berbeda dari soto bogor yang ada di wilayah Munjul. Soto Mie Bogor Pak Jaja Munjul produk yang dihasilkan oleh Soto Mie Bogor Pak Jaja Munjul memiliki 2 macam soto yang berbeda yaitu soto mie santan dan soto mie berkuah bening. Adapun isian soto terdiri dari daging, kikil, ayam dan jeroan seperti babat, usus dan lain-lain. Untuk soto santan terdapat potongan kentang di dalamnya yang menjadikan Soto Mie Bogor Pak Jaja Munjul berbeda dari soto lainnya. Selain soto, usaha mikro soto mie Bogor Pak Jaja juga menyediakan pelengkap seperti nasi dan kerupuk dan minuman berupa es teh manis dan kopi.

b) Harga (Price)

Harga yang ditawarkan oleh Soto Mie Bogor Pak Jaja Munjul berbedabeda untuk harga soto dan nasi Rp. 16.000 sedangkan untuk sotonya saja Rp. 13.000 dan untuk nasinya saja Rp. 3.000, kerupuk Rp. 1.000,-, es teh manis dan kopi masing-masing Rp. 3.000,-

Dalam menentukan kebijakan harga Soto Mie Bogor Pak Jaja Munjul tidak memiliki kebijakan khusus hanya menggunakan harga rata-rata pasaran dan kemampuan daya beli masyarakat dengan memberikan harga soto dan nasi Rp. 16.000. hal ini berdasarkan hasil survey awal sebelum membuka usaha Soto Mie Bogor Pak Jaja Munjul.

Pak Jaja juga tidak menerapkan adaptasi ataupun diskriminasi harga sehingga untuk pelanggan Soto Mie Bogor Pak Jaja Munjul yang melakukan pemesanan soto dengan jumlah banyak pemilik Soto Mie Bogor Pak Jaja Munjul tidak memberikan potongan harga.

Dibandingkan dengan harga ditempat lain, harga yang ditawarkan oleh 
pengelola Soto Mie Bogor Pak Jaja Munjul sangat terjangkau dibandingkan ditempat lain. Harga yang ditawarkan ditempat lain satu porsi soto saja sebesar Rp.15.000. Namun sejak tahun 2019 Pak Jaja menaikkan harga satuan per porsi soto santan menjadi Rp. 15.000 per porsi sedangkan harga untuk produk lain masih sama.

c) Tempat (Place)

Untuk menikmati Soto Mie Bogor Pak Jaja Munjul maka konsumen dapat datang ke Jalan Raya Munjul Rt 003 Rw 01 Kelurahan Munjul Kecamatan Cipayung dan pemilik belum menggunakan layanan aplikasi pada ojek online serta tidak menawarkan layanan pesan-antar.

d) Promosi (Promotion)

Diawal pembukaan usaha, pemilik Soto Mie Bogor Pak Jaja Munjul membuat promosi dengan cara membuat pamflet yang menarik kemudian di sebar ke masyarakat di wilayah Munjul dan di sebar untuk para pejalan kaki yang melewati Soto Mie Bogor Pak Jaja Munjul selain itu pemilik juga menyebarkan brosur ke para pengguna motor dan mobil yang melawati wilayah Munjul. Selain itu, pemilik menawarkan produk dengan harga pada masa promosi sebesar Rp. 13.000 untuk paket nasi dan soto.

Saat ini, bauran promosi yang gunakan oleh Soto Mie Bogor Pak Jaja Munjul dengan menggunakan bauran promosi dari mulut ke mulut karena konsumen lebih suka mencoba produk terlebih dahulu kemudian konsumen memberitahu kepada masyarakat atau rekan-rekan konsumen sehingga konsumen percaya akan produk yang dinikmatinya. Bauran promosi dari mulut ke mulut sangat membantu Soto Mie Bogor Pak Jaja karena bauran promosi tersebut tidak membutuhkan dana, bauran promosi dari mulut ke mulut lebih cepat di dengar oleh konsumen dan konsumen yang mencoba akan percaya dengan kelezatan Soto Mie Bogor Pak Jaja Munjul.

e) Proses

1) Jam Operasional Soto Mie Bogor Pak Jaja Munjul

Untuk jam operasional Soto Mie Bogor Pak Jaja Munjul buka pukul 08.00 WIB sampai dengan pukul 16.00 WIB. Dan Soto Mie Bogor Pak Jaja Munjul buka setiap hari untuk hari raya libur, jika tidak berjualan pengelola memberi tahu dengan membuat pemberitahuan di depan kaca gerobak.

2) Proses Pemesanan

Dalam proses pemesanan Soto Mie Bogor Pak Jaja Munjul tidak ada cara khusus dalam memesan Soto Mie Bogor Pak Jaja Munjul konsumen cukup datang ke tempat Soto Mie Bogor Pak Jaja Munjul kemudian pesan di tempat.

3) Proses Pembayaran

Dalam proses pembayaran pemilik Soto Mie Bogor Pak Jaja Munjul tidak menggunakan kasir hanya saja konsumen langsung membayar soto jika sudah selesai makan kepada pelayan Soto Mie 
Vol 1, No. 1 (2020), June 2020

E-ISSN: 2746-2471

Bogor Pak Jaja Munjul, jika konsumen membawa pulang soto konsumen dapat membayar kepada pelayan yang memberi soto tersebut.

f) Orang (People)

Soto Mie Bogor Pak Jaja Munjul memiliki karyawan dengan jumlah 2 orang karyawan. Untuk kinerja karyawan Soto Mie Bogor Pak Jaja Munjul cukup baik dan disiplin karena karyawan Soto Mie Bogor Pak Jaja Munjul menyiapkan dagangannya atau merapihkan dagangannya pukul 05.00 pagi sampai dengan pukul 07.00 kemudian pukul 08.00 Soto Mie Bogor Pak Jaja Munjul sudah buka.

Dalam kualifikasi setiap personil yang dibutuhkan oleh Soto Mie Bogor Mie Bogor Pak Jaja Munjul setiap karyawan harus rapih dalam berpakaian dan harus sopan dalam melayani konsumen agar konsumen nyaman dan tertarik dengan pelayanan yang diberikan oleh Soto Mie Bogor Pak Jaja Munjul. Kemampuan yang dimiliki oleh setiap personil sudah sesuai dengan kebutuhan yang diinginkan oleh Soto Mie Bogor Pak Jaja Munjul. Karyawan Soto Mie Bogor Pak Jaja Munjul merupakan sepasang suami istri sehingga karyawan dengan mudah bekerja sama dengan baik dalam mengelola Soto Mie Bogor Pak Jaja Munjul. Karyawan Soto Mie Bogor Pak Jaja Munjul tidak memiliki seragam khusus pada saat berjualan, karyawan hanya menggunakan pakaian bebas, rapih dan sopan.

g) Bukti Fisik (Physical Evidence)

Kondisi bangunan yang dimiliki Soto Mie Bogor Pak Jaja Munjul layak hanya saja jembatan penyebrangan untuk ke Soto Mie Bogor Pak Jaja Munjul tidak layak karena jembatan penyebrangan rusak dan hanya terbuat dari kayu seadanya. Untuk kondisi bangunan Soto Mie Bogor Pak Jaja terbuat dari bahan semi permanen yang tidak bisa di bongkar pasang, sedangkan alasnya tidak diberi keramik, dan untuk menutupin pelanggan yang sedang makan hanya menggunakan triplek dan di beri kawat di atasnya agar ada udara masuk kedalam.

Fasilitas yang diberikan oleh Soto Mie Bogor Pak Jaja Munjul yaitu konsumen dapat menonton televisi pada saat menikmati Soto Mie Bogor Pak Jaja Munjul dan pemilik Soto Mie Bogor Pak Jaja Munjul menyediakan colokan untuk konsumen mengisi daya handphone.

Di Soto Mie Bogor Pak Jaja Munjul tidak ada kipas angin hanya mengandalkan angin dari luar, selain itu parkiran di Soto Mie Bogor Pak Jaja Munjul hanya cukup untuk motor saja jika ada konsumen yang ingin makan dengan menggunakan mobil bisa saja teapi hanya bisa untuk 1 mobil saja dan parkir di pinggir jalan depan Soto Mie Bogor Pak Jaja Munjul

h) Produktivitas dan Kualitas (Productivity and Quality)

Produktivitas yang dijalankan oleh pengelola Soto Mie Bogor Pak Jaja Munjul yaitu mampu mempertahankan penjualan perhari 20 sampai 50 porsi per hari. Dengan jam operasional pukul 09.00 sampai dengan pukul 16.00. sedangkan untuk memastikan kualitas rasa yang dimiliki oleh Soto Mie Bogor 
Vol 1, No. 1 (2020), June 2020

E-ISSN: 2746-2471

Pak Jaja Munjul maka dalam pembuatan bumbu dan kuah dilakukan sendiri oleh istri pemilik. Adapun kuantitas bumbu yang dibuat, dipersiapkan untuk satu minggu.

Untuk mengukur produktivitas karyawan Soto Mie Bogor Pak Jaja Munjul memiliki 3 cara yaitu 1) harus pandai memasak 2) karyawan harus pandai menjamu konsumen. 3) karwayan harus jujur dan displin dalam menjalankan dan mengelola keuangan.

3. Pengendalian dan Evaluasi Hasil

Program bauran pemasaran yang dijelaskan sebelummnya telah berjalan selama usaha mikro Soto Mie Bogo Pak Jaja didirikan. Adapun hasil dari dari pelaksanaan program tersebut dapat dilihat pada tabel 1 dan tabel 2. Berdasarkan data pada tabel 1 dan 2 diketahui bahwa penjualan usaha mikro Soto Mie Bogor Pak Jaja mengalami penurunan setiap tahunnya antara 9\% - 34\% atau rata-rata sebesar 8,06 \% selama 7 tahun berdiri. Hal ini menunjukan bahwa kegiatan pemasaran yang telah dilakukan selama ini belum efektif untuk meningkatkan penjualan. Program tersebut hanya dapat menjaga usaha mikro Soto Mie Bogor Pak Jaja tetap berjalan. Selain itu harga dan produk yang ditawarkan juga merupakan produk kuliner yang umum dan sulit untuk membuat perbedaan antara kuliner sejenis kecuali dari rasa yang di tawarkan namun akan sulit jika memang konsumen tidak dapat membedakan rasa tersebut.

Tabel 1. Data Penjualan Usaha Mikro Soto Mie Bogor Pak Jaja

Periode 2013-2019

\begin{tabular}{cccccc}
\hline Tahun & \multicolumn{5}{c}{ Produk (Porsi) } \\
\cline { 2 - 6 } & $\begin{array}{c}\text { Soto } \\
\text { Mie }\end{array}$ & $\begin{array}{c}\text { Soto } \\
\text { Santan }\end{array}$ & Nasi & $\begin{array}{c}\text { Es Teh } \\
\text { Manis }\end{array}$ & $\begin{array}{c}\text { Total } \\
\text { penjualan }\end{array}$ \\
\hline 2013 & 11.973 & 9.342 & 7.230 & 6.120 & 34.665 \\
2014 & 14.526 & 10.063 & 8.659 & 7.200 & 40.448 \\
2015 & 10.890 & 8.103 & 6.465 & 5.400 & 30.858 \\
2016 & 9.931 & 7.492 & 5.021 & 4.680 & 27.124 \\
2017 & 8.907 & 6.574 & 4.533 & 3.960 & 23.974 \\
2018 & 7.956 & 5.942 & 3.251 & 2.880 & 20.029 \\
2019 & 7.956 & 5.942 & 3.251 & 2.880 & 20.029 \\
\hline Jumlah & 72.139 & 53.458 & 38.410 & 33.129 & 197.118 \\
\hline \multicolumn{5}{l}{ Sumber: Soto Mie Bogor Pak Jaja Munjul (2020) }
\end{tabular}

Tabel 2. Pendapatan Usaha Mikro Soto Mie Bogor Pak Jaja

Periode 2013-2019

Dalam Rupiah

\begin{tabular}{cccccc}
\hline \multirow{2}{*}{ Tahun } & \multicolumn{5}{c}{ Produk (Rupiah) } \\
\cline { 2 - 6 } & Soto Mie & Soto Santan & Nasi & $\begin{array}{l}\text { Es teh } \\
\text { manis }\end{array}$ & $\begin{array}{c}\text { Total } \\
\text { penjualan }\end{array}$ \\
\hline 2013 & 155.649 .000 & 121.446 .000 & 21.690 .000 & 18.360 .000 & 317.145 .000 \\
2014 & 188.838 .000 & 130.819 .000 & 25.977 .000 & 21.600 .000 & 367.234 .000
\end{tabular}


Vol 1, No. 1 (2020), June 2020

E-ISSN: 2746-2471

\begin{tabular}{cccccc}
2015 & 141.570 .000 & 105.339 .000 & 19.395 .000 & 16.200 .000 & 282.504 .000 \\
2016 & 129.103 .000 & 97.396 .000 & 15.063 .000 & 14.040 .000 & 255.602 .000 \\
2017 & 115.791 .000 & 85.462 .000 & 13.599 .000 & 11.880 .000 & 226.732 .000 \\
2018 & 103.428 .000 & 77.246 .000 & 9.753 .000 & 8.640 .000 & 199.067 .000 \\
2019 & 103.428 .000 & 89.130 .000 & 9.753 .000 & 8.640 .000 & 210.951 .000 \\
\hline Jumlah & 937.807 .000 & 706.838 .000 & 115.230 .000 & 99.360 .000 & 1.859 .235 .000 \\
\hline
\end{tabular}

Sumber: data dioleh berdasarkan informasi pemilik (2020)

Tabel 3. Total Biaya Per Porsi

\begin{tabular}{lccc}
\hline \multicolumn{1}{c}{ Produk } & $\begin{array}{c}\text { Biaya } \\
\text { variabel } \\
(\mathrm{Rp})\end{array}$ & $\begin{array}{c}\text { Biaya } \\
\text { Tetap } \\
(\mathrm{Rp})\end{array}$ & $\begin{array}{c}\text { Total Biaya } \\
\text { per porsi } \\
(\mathrm{Rp})\end{array}$ \\
\hline Soto Mie & 9.780 & 1.360 & 11.140 \\
Soto Santan & 14.700 & 1.360 & 16.060 \\
Nasi & 800 & 1.360 & 2.160 \\
Es teh manis & 500 & 1.360 & 1.860
\end{tabular}

Sumber: data dioleh berdasarkan informasi pemilik (2020)

Selain itu, penetapan harga yang digunakan menunjukkan bahwa terdapat kesalahan perhitungan. Dengan kata lain, harga yang ditetapkan tidak memberikan keuntugan yang signifikan. Tabel 3 menunjukkan total biaya untuk setiap produk sedangkan Tabel 4 menunjukkan hasil perhitungan analisis profitabilitas dari setiap produk yang ditawarkan oleh Usaha Mikro Soto Mie Bogor Pak Jaja.

Tabel 4. Percentage Variable Contribution Margin Usaha Mikro Soto Mie Bogor Pak Jaja

Periode 2013-2019

\begin{tabular}{lll}
\hline No. & Tahun & PVCM \\
\hline 1. & 2013 & $16.99 \%$ \\
2. & 2014 & $18.17 \%$ \\
3. & 2015 & $17.35 \%$ \\
4. & 2016 & $16.43 \%$ \\
5. & 2017 & $16.48 \%$ \\
6. & 2018 & $15.00 \%$ \\
7. & 2019 & $19.79 \%$ \\
\hline \multicolumn{3}{c}{ Sumber: data diolah $(2020)$}
\end{tabular}

Tabel 5. Percentage Variable Contribution Margin Per Produk Usaha Soto Mie Bogor Pak Jaja

\begin{tabular}{lll}
\hline No. & Produk & PVCM \\
\hline 1. & Soto Mie & $24.77 \%$ \\
2. & Soto Santan $^{*}$ & $(13.08 \%)$ \\
3. & Soto Santan & $2.00 \%$ \\
4. & Nasi & $73.34 \%$ \\
5. & Es The Manis & $83.34 \%$ \\
\hline
\end{tabular}


Berdasarkan data yang ada, usaha mikro Soto Mie Bogor Pak Jaja memperoleh rata-rata PVCM selama periode 2013-2019 sebesar 17,17\% dengan PVCM tertinggi diperoleh pada tahun 2019 sebesar 19,79\% dan yang terendah di tahun 2018 sebesar 15\%. Sedangkan untuk PVCM setiap produk menunjukkan bahwa soto santan memberikan nilai PVCM (lihat pada tabel 5) paling rendah, terlihat pada produk soto santan di periode tahun 2013-2018 PVCM negatif sebesar 13,08\% dan pada tahun 2019 setelah pemilik menaikkan harga jual soto santan dari Rp. 13.000,- menjadi Rp. 15.000,sehingga PVCM menjadi positif sebesar 2\%. Dilihat dari hasil perhitungan semakin tinggi harga produk maka semakin tinggi kontribusi variabelnya.

Hal tersebut disebabkan karena persentase keuntungan yang ditetapkan dalam penentuan harga diberlakukan berbeda. Kebijakan Soto Mie Bogor Pak Jaja Munjul menentukan bahwa semakin banyak kuantitas produk yang dijual oleh konsumen maka semakin tinggi keuntungan. Hal ini dapat dilihat pada contoh kasus berikut:

a. Penjualan untuk soto mie dengan harga jual Rp. 13.000, dengan jumlah porsi 30 per hari.

Penjualan $=$ Rp. $13.000 \times 30=$ Rp. 390.000

Keuntungan $=$ Rp. $3.220 \times 30=$ Rp. 96.000

b. Penjualan untuk soto santan dengan harga jual Rp. 13.000, dengan jumlah porsi 20 per hari (periode 2013-2018)

Penjualan $=$ Rp. $13.000 \times 20=$ Rp. 260.000

Rugi $=$ Rp $-1.700 \times 20=$ Rp. -34.000

c. Penjualan ntuk soto santan dengan harga jual Rp. 15.000, dengan jumlah porsi 20 per hari. (tahun 2019)

Penjualan $=$ Rp. $15.000 \times 20=$ Rp. 360.000

Keuntungan $=\operatorname{Rp} 300 \times 20=$ Rp. 6.000

d. Penjualan untuk nasi harga jual Rp. 3.000 dengan jumlah 25 piring perhari.

Penjualan $=$ Rp. $3.000 \times 25=$ Rp. 75.000

Keuntungan $=$ Rp. $2.220 \times 25=$ Rp. 55.000 
e. Penjualan es teh manis dengan harga jual Rp.Penjualan es teh manis dengan harga jual Rp. 3.000 dengan jumlah 30 gelas per hari.

Penjualan $=$ Rp. $3.000 \times 30=$ Rp. 90.000

Keuntungan $=$ Rp. $2.500 \times 30=$ Rp. 75.000

Dari contoh perhitungan di atas, dapat dilihat bahwa meskipun persentase keuntungan per porsinya lebih kecil namun keuntungan secara total yang diperoleh Soto Mie Bogor Pak Jaja Munjul justru lebih besar pada penjualan soto mie hal ini karena kontribusi penjualan mencapai $50 \%$ dari keseluruhan total pendapatan selama 7 tahun (2013-2019). Sehingga dapat diketahui bahwa ternyata strategi pemasaran yang telah diterapkan memiliki kekurangan yaitu:

a. Tidak adanya perbedaan produk yang signifikan sehingga tidak memiliki daya saing

b. Penetapan harga yang tidak sesuai dengna biaya yang dikeluarkan menyebabkan terjadinya kerugian. Walaupun usaha mendapat untung namun tidak memberikan dampak signifikan pada perubahan dan perkembangan usaha

c. Dilihat dari sisi tempat bisa dikatakan usaha ini hanya menyediakan tempat seadanya untuk makan dan tidak bekerjasama dengan layanan ojek online ataupun penyedia aplikasi lainnya.sehingga jangkuannya hanya pada wilayah sekitar tempat usaha.

d. Kekurangan mengkomunikasikan produk karena hanya mengandalkan testimoni konsumen dan ini cukup beresiko karena rasa sangat berbeda bagi setiap orang

e. Tidak adanya fasilitas membuat usaha ini hanya menwarkan produk utama tanpa adanya layanan tambahan dan pendukung.

f. Penetapaan kebijakan mengenai karyawan seharusnya juga diperhitungkan dalam penetapan harga.

\section{E. SIMPULAN}

Berdasarkan hasil penelitian maka dapat disimpulkan bahwa penetapan strategi dan program pemasaran yang dilakukan oleh usaha mikro Soto Mie Bogor tidak efektif sehingga perlu adanya pendampingan bagi pemilik agar dapat mengelola dan mengembangkan usahanya tidak hanya sekedar memiliki usaha. 


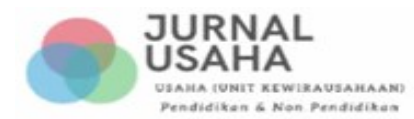

Vol 1, No. 1 (2020), June 2020

E-ISSN: 2746-2471

\section{DAFTAR PUSTAKA}

Assauri, S. (2015). Manajemen Pemasaran. Jakarta: Rajawali Pers.

Barney, J. B. (1991). Firm resources and sustained competitive advantage. Journal of Management, 17: 99-120.

Booms B. H. dan Bitner M. J. (1981). Marketing Strategies and Organizational Structures for Services Firms. Dalam J. Donnelly dan W. George (Eds), Marketing Services. Chicago. American Marketing Association

Creven, David W. and Piercy, Nigel F. (2013). Strategic Marketing. Tenth Edition. International Edition. New York. McGraw Hill Education

Elsandara, Y dan Yulianto, A.A. (2015). Strategi Pemasaran Untuk Meningkatkan Usaha Kecil Menengah Berbasis Industri Kreatif Melalui ICT. Jurnal Kajian Manajemen Bisnis, 2 (1) hlm.31-42.

Flick, U., Steinke, I. dan Kardoff, E.V. (2017). Buku Induk Penelitian Kualitatif: Paradigma, Teori, Metode, Prosedur, dan Praktik. Yogyakarta. Cantrik Pustaka.

Heriyoga, R. (2014). Analisis Strategi Pemasaran UMKM Menggunakan Pendekatan Kualitatif Fenomenologi dalam Era MEA. Prosiding Seminar Nasional Psikologi UMG, hlm 277-296.

Huberman, A. M dan Miles, M. B. (2002). The Qualitative Researcher's Companion. California. Sage Publications, Inc

Kotler, Philip and Kevin Lane Keller. 2016. Marketing Management. 15th Ed. Global Edition. England. Pearson Education Limited

Lovelock, C.H dan Lauren K.W. (2002). Principles of Services Marketing and Management. USA. Prentice Hall International

PESTLEAnalysis.com (2018). What is PESTLE Analysis? A tool for business analysis. [online]. Diakses di http://pestleanalysis.com/whataispestleanalysis?atoolforbussinessanalysis Pada 14 Mei 2018 jam 5:41

Solihin, Ismail. (2012). Manajemen Strategik. Jakarta. Erlangga

Tjiptono, F. (2015). Strategi Pemasaran. Edisi empat. Yogyakarta: CV Andi Offset.

Tjiptono, Fandy dan Gregorius Chandra. (2015). Pemasaran Strategik. Jakarta: CV Andi Offset.

Undang-undang Nomer 20 Tahun 2008 pasal 6 tentang Usaha Mikro, Kecil dan Menengah.

Wibowo, D.H dan Sunarti. (2015) Analisis Strategi Pemasaran Untuk Meningkatkan Daya Asing UMKM (Studi pada Batik Diajeng Solo). Jurnal Administrasi Bisnis (JAB), 29 (1) hlm 59-66

Wirtz, J. dan Lovelock, C. (2018). Essential of Services Marketing. $3^{\text {rd }}$ Edition. England. Pearson Education Limited. 